\title{
Evaluation of the respiratory health of dock workers who load grain cargoes in British Columbia
}

\author{
Helen D Dimich-Ward, Susan M Kennedy, Michelle A Dittrick, Anne DyBuncio, \\ Moira Chan-Yeung
}

\begin{abstract}
Objectives-To investigate the respiratory health of dock workers who load grain cargoes.

Methods-The respiratory health of 118 dock workers who load grain cargoes in the ports of Vancouver and Prince Rupert was compared with that of 555 grain elevator workers from the same regions. 128 civic workers were used as an unexposed control group.

Results-The prevalances of chronic cough and phlegm were at least as high in dock workers as those found in the elevator workers, and when adjusted for differences in duration of employment and smoking, dock workers had an eightfold higher risk of developing chronic phlegm than did civic workers. Symptoms of eye and skin irritation that were experienced at least monthly were highest for dock workers. Average percentage of the predicted $\mathrm{FEV}_{1}$ and FVC for dock workers (mean $100 \cdot 6 \%$ and $105 \cdot 3 \%$ respectively) were similar to the civic workers but significantly higher than those found for elevator workers. Higher subjective estimates of duration of exposure to grain dust (hours/day) were associated with lower values of $\mathrm{FEV}_{1}$.

Conclusions-The more intermittent grain dust exposure patterns of dock workers may have allowed for some recovery of lung function, but chronic respiratory symptoms were less labile.
\end{abstract}

(Occup Environ Med 1995;52:273-278)

Environmental and

Diseases Research

Unit, Respiratory

Division, Department

of Medicine,

University of British

Columbia, Vancouver,

Canada

H D Dimich-Ward

$S$ M Kennedy

M A Dittrick

A DyBuncio

M Chan-Young

Correspondence to:

Dr Helen Dimich-Ward,

Environmental and

Occupational Lung Diseases

Research Unit, Respiratory

Division, University of

British Columbia,

Department of Medicine,

Vancouver General

Hospital,

2775 Heather Street,

Vancouver,

British Columbia, Canada,

V5Z 3J5.

Accepted 1 December 1994

Keywords: lung function; respiratory symptoms; dock workers; grain dust

Much of our knowledge of the respiratory hazards of grain dust is based upon epidemiological studies of grain processing workers at country or terminal elevators. For instance, grain elevator workers and a control group of indoor civic workers in Vancouver have been subjects of six repeated cross sectional studies that have taken place about every three years since 1975. An analysis of each of the first five studies consistently showed that the elevator workers had more respiratory symptoms and lower lung function than the civic workers, even after adjustment for smoking. ${ }^{1}$ Such respiratory effects that are related to exposure to grain dust have been found repeatedly in many countries. ${ }^{2}$
In the port of Vancouver there are five grain elevator terminals, and Prince Rupert has the only other coastal grain export terminal in British Columbia. Railway wagons containing wheat, barley, rye, or canola from the Canadian prairies are unloaded at the elevator terminals. After sorting, grading, weighing, binning, drying, and cleaning, the grain is then stored in concrete silos. For shipment, the grain is transported through galleries by conveyer belts to the dock area. Up to this stage elevator workers perform all the duties.

Dock workers operate remote consoles or use a system of rope guides to direct pipes, through which about 300 to 900 metric tonnes of grain are loaded an hour. When each of the ship's holds is near capacity, the dock workers shovel the grain inside the hold to distribute it more evenly.

There have been few epidemiological studies of dock workers ${ }^{34}$ and none that compare the exposure characteristics and health effects for the two different groups exposed to grain. The purpose of this study was to compare lung function and symptoms of dock workers who load grain cargoes with a control group of civic workers who were not occupationally exposed to either grain or other dusts. Also, comparison was made with grain elevator workers who work in the vicinity of these dock areas to determine what characteristics of exposure to grain dust were related to decline in lung function.

\section{Methods}

SUBJECTS

All non-clerical union employees from the six grain elevators in British Columbia and dock workers who were identified by their union as working regularly on grain ships were sent a letter that invited them to participate in the study. The participation rate of the invited dock workers was $83 \%(n=118)$, which compared favourably with the rate of $85 \%$ for the survey of grain elevator workers $(n=555)$. Elevator workers were studied from February to April of 1991 whereas dock workers were studied during the months of October to December of that year. A comparison group of 128 professional workers and clerks from Vancouver City Hall were studied in September 1991, and $60 \%$ of those invited participated.

A secondary analysis was performed to allow a comparison of grain fever and other symptoms of exposure to grain dust between 
dock and elevator workers. Because the questions were not included in the 1991 grain workers' survey, the responses of 524 grain elevator workers who were studied in 1988 were used. ${ }^{5}$

\section{HEALTH MEASUREMENTS}

All research protocols received ethics committee approval and each subject gave informed written consent before testing. The same protocol was followed for each study. The questionnaire was given by trained interviewers. The American Thoracic Society questionnaire recommended for epidemiological study of chronic respiratory diseases was the basis of the medical history section. ${ }^{6}$ Questions on general health, acute symptoms, and occupational exposures were added. Subjective estimates of the extent of the exposure to grain dust were obtained by questioning the workers about the average frequency (number of days a week or month) and duration (number of hours a day) of exposure to grain dust.

The subject's height and weight were measured. Skin prick tests were conducted with three common allergens: house dust mite (Dermatophagoides farinae), mixed grass pollen, and cat epidermal antigen (Bencard Allergy Service, Mississauga, Ontario). Saline and histamine were used as the negative and positive controls respectively. If the wheal diameter, measured after 15 minutes, was found to be over $3 \mathrm{~mm}$ or greater than the negative control, the response was considered positive.

The same technicians conducted spirometry tests for all three studies. A Collins 13.5 1 water sealed spirometer (Warren E Collins, Baintree, MA) was used each time according to standardised techniques recommended by the American Thoracic Society. ${ }^{7}$ A minimum of five forced expiratory manoeuvres were performed, with the workers seated and wearing nose clips. The highest forced expiratory volume in one second $\left(\mathrm{FEV}_{1}\right)$ and forced vital capacity (FVC) from the spirograms were recorded; the maximum midexpiratory flow rate $(M M F)$ was derived from the spirogram

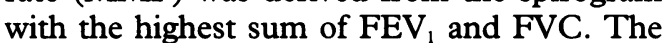
end of the test was determined by visual inspection of the trace until a minimum of a two second plateau was reached. The results were converted to body temperature, pressure, and saturation (BTPS) and expressed in $\mathrm{ml}$ and as a percentage of the predicted values. The equations used were based on sex, age, and height as derived from Crapo et al ${ }^{8}$ with modifications for race, so that non-white people had a predicted value $85 \%$ of that of white people.

\section{DUST MEASUREMENTS}

Personal and area measurements for total dust were conducted by Labour Canada technicians. Grain dust was collected in a $37 \mathrm{~mm}$ diameter preweighed polyvinyl chloride filter of $0.8 \mu$ pore size held in a two piece plastic cassette. The flow rate of the Dupont P4LC air pump (Amatek, Largo, FL) to which the filter was attached, was calibrated to run at 1.71 a minute. Personal measurements were collected by attaching the pump to the subject's belt and securing the tubing so that the cassette was in his breathing zone.

Grain dust samples were taken for the dock workers over a period of eight weeks from October to December of 1991 on five ships that were being loaded with either wheat, barley, or oilseed at the terminal elevators. For area measurements, air pumps were positioned at either side of at least one hold of a ship. Personal sampling ranged from one to two hours in duration, and the concentration of dust for the work day was calculated as a weighted average of the separate measurements, according to the sampling time. The mean (range) of total duration was three (one to eight) hours.

An environmental assessment of the grain elevators was also performed periodically throughout 1991 with the same standard method and stratified random sampling approach that has been used for previous studies on grain elevators. Personal dust samples were taken from a representative sample of workers according to job title and work areas at all six British Columbian grain elevators; area sampling was also done. The sampling time was taken to represent exposure during a working day and ranged from five to eight hours in duration.

\section{STATISTICAL ANALYSIS}

Data were coded, key punched, and verified. All analyses were conducted with the statistical software SPSS-PC + version $4 \cdot 0$ (SPSS Chicago, Il). Univariate analyses of proportions were done with the $\chi^{2}$ test. A multiple logistic regression analysis for binary outcomes was used to adjust for confounding factors. For continuous dependent variables, two groups were compared with Student's $t$ tests, and for three groups, a one way analysis of variance was used. Multiple regression analyses were used to adjust for confounding factors.

\section{DEFINITIONS}

Non-smokers-Those who had never smoked or had smoked less than one cigarette a day for a year, or an equivalent amount of pipe tobacco or cigars. Current smokersThose who smoked within one month of the study. Ex-smokers-Those who had given up smoking at least one month before the survey. Atopy-Those who had a positive reaction to at least one of the three common allergens. Chronic cough-Those who had a cough on most days over three consecutive months of each year. Chronic phlegm-Those who brought up phlegm on most days over three consecutive months of each year. Occasional wheeze-Those who had occasional wheeze, apart from colds. DyspnoeaThose who were breathless when hurrying on level ground or when walking up a slight hill. Grain fever-Those who had a fever and chills and either headache, muscle ache, or facial flushing associated with exposure to grain. 
Table 1 Characteristics of dock, elevator, and civic workers

\begin{tabular}{|c|c|c|c|}
\hline Variable & Dock & Elevator & Civic \\
\hline No & 118 & 555 & 128 \\
\hline Race (white \%) * & 92.4 & 91.9 & $80 \cdot 5$ \\
\hline Age $(y)^{\star}$ & $43.9(9.9)$ & $41 \cdot 3(10 \cdot 1)$ & $45 \cdot 6(9 \cdot 7)$ \\
\hline Height $(\mathrm{cm})$ & $177 \cdot 2(6 \cdot 8)$ & $175 \cdot 5(7 \cdot 3)$ & $176 \cdot 0(7 \cdot 4)$ \\
\hline Weight $(\mathrm{kg})^{\star}$ & $88.8(15 \cdot 6)$ & $87 \cdot 4(14 \cdot 1)$ & $80.9(13.5)$ \\
\hline \multicolumn{4}{|l|}{ Smoking (\%) } \\
\hline Non-smokers & $22 \cdot 0$ & $33 \cdot 7$ & $46 \cdot 9$ \\
\hline Ex-smokers & $37 \cdot 3$ & $37 \cdot 8$ & $43 \cdot 0$ \\
\hline Current smokers & $40 \cdot 7$ & $28 \cdot 5$ & $10 \cdot 1$ \\
\hline Duration of smoking $(y)$ & $18 \cdot 3(11 \cdot 2)$ & $17 \cdot 1(10 \cdot 4)$ & $15 \cdot 8(8 \cdot 8)$ \\
\hline Mean (SD) age began smoking (y) & $15.9(3.9)$ & $16.5(3.5)$ & $17 \cdot 4(3 \cdot 9)$ \\
\hline Mean (SD) cigarettes/day (n) & $18.9(10 \cdot 8)$ & $19 \cdot 4(11 \cdot 5)$ & $19 \cdot 2(11 \cdot 5)$ \\
\hline Atopy (positive \%)^ & $16 \cdot 4$ & $29 \cdot 4$ & $26 \cdot 5$ \\
\hline Work in industry $(y)^{\star}$ & $21 \cdot 5(8 \cdot 5)$ & $14 \cdot 7(8 \cdot 7)$ & $19 \cdot 9(11 \cdot 7)$ \\
\hline
\end{tabular}

${ }^{\star} \mathrm{P}<0.05 \chi^{2}$ test for differences in proportions and one way analysis of variance for continuous variables.
EXPOSURE TO GRAIN DUST

For the dock workers, excessive grain dust exposure was attributed to the work activity of finishing off the holds and loading particular types of grains, of which barley was most commonly regarded as being the dustiest (data not shown). Table 2 shows the frequency of questionnaire responses about the average extent of exposure to grain dust and of dust measurements. The intermittent exposure of the dock workers to grain is apparent in the evaluation of the questionnaire, in that most $(57 \%)$ dock workers handled grain cargoes less than five days a week, and the estimated periods of grain exposure during their working day were significantly lower, with $57 \%$ of the dock workers perceiving their exposure to grain dust to be less than four hours a day (which contrasts with $36 \%$ of elevator workers). The dock workers were more likely to use masks for respiratory protection during exposure to grain, than were the grain elevator workers. The elevator workers on average, worked more overtime (30 $v$ 19.1 hours a month) as well as being continuously exposed to grain dust during the working week. More of the area samples from the ships' hold than those from inside the grain elevators were over the Canadian permissible concentration of $10 \mathrm{mg} / \mathrm{m}^{3}(14.7 \% v 1.9 \%)$ indicating a potential for higher exposure in the dock workers. The dust concentrations measured by personal sampling were found to be similar in distribution. There were also no significant difference between the sample means. current smokers, in contrast with only $10 \%$ the civic workers and $29 \%$ of the elevator workers. The prevalence of atopy was almost twice as high in the elevator and civic workers than the $16 \%$ found in the dock workers.

Table 2 fob characteristics of dock and elevator workers

\begin{tabular}{|c|c|c|}
\hline & Dockt & Elevator \\
\hline Full time $(\%)^{\star}$ & $90 \cdot 6$ & $100 \cdot 0$ \\
\hline $\begin{array}{l}\text { Means (SD) monthly overtime } \\
\text { (h) }\end{array}$ & $19 \cdot 1(21 \cdot 0)$ & $30 \cdot 0(20 \cdot 4)$ \\
\hline Usually used mask $(\%)^{\star}$ & $57 \cdot 3$ & $28 \cdot 8$ \\
\hline Type of mask used (\%):* & & \\
\hline Filter mask & $86 \cdot 2$ & $97 \cdot 6$ \\
\hline Twin cartridge & $13 \cdot 8$ & $2 \cdot 4$ \\
\hline \multicolumn{3}{|l|}{$\begin{array}{l}\text { Estimates of exposure based on } \\
\text { questionnaire }(\%): \\
\text { Duration }(\mathrm{h} / \mathrm{day}):^{\star}\end{array}$} \\
\hline $\begin{array}{l}<2 \\
2-4 \\
4-6 \\
>6\end{array}$ & $\begin{array}{l}24 \cdot 6 \\
32 \cdot 5 \\
25 \cdot 4 \\
17 \cdot 5\end{array}$ & $\begin{array}{l}20 \cdot 5 \\
15 \cdot 9 \\
32 \cdot 7 \\
30 \cdot 9\end{array}$ \\
\hline \multicolumn{3}{|l|}{ Frequency (days/week): ${ }^{\star}$} \\
\hline$<1$ & $12 \cdot 0$ & 0 \\
\hline $1-3$ & $22 \cdot 2$ & 0 \\
\hline $3-5$ & $23 \cdot 1$ & 0 \\
\hline$\geqslant 5$ & $42 \cdot 7$ & 100 \\
\hline \multicolumn{3}{|l|}{$\begin{array}{l}\text { Grain dust measurements } \\
\left.\text { (mg/m } \mathrm{m}^{3} \%\right) \\
\text { Personal samples: }\end{array}$} \\
\hline No & 27 & 134 \\
\hline Geometric mean (SD) & $1.77(4.35)$ & $1.64(3.80)$ \\
\hline Distribution: & & \\
\hline $\begin{array}{l}<4 \\
4-10\end{array}$ & $\begin{array}{l}66 \cdot 7 \\
22 \cdot 2 \\
-1 \cdot 2\end{array}$ & $\begin{array}{r}76 \cdot 7 \\
15 \cdot 1 \\
8 \cdot 2\end{array}$ \\
\hline $\begin{array}{l}>10 \\
\text { Area samples: }\end{array}$ & & \\
\hline $\begin{array}{l}\text { No } \\
\text { Geometric mean (SD) }\end{array}$ & $\begin{array}{l}34 \\
1 \cdot 6(5 \cdot 3)\end{array}$ & 114 \\
\hline $\begin{array}{l}\text { Distribution:^ } \\
\quad 44 \\
\quad 4-10 \\
>10\end{array}$ & $\begin{array}{l}64 \cdot 1 \\
20 \cdot 6 \\
14 \cdot 7\end{array}$ & $\begin{array}{r}85 \cdot 8 \\
12 \cdot 3 \\
1 \cdot 9\end{array}$ \\
\hline
\end{tabular}

${ }^{\star} \mathrm{P}<0.05 \chi^{2}$ test for differences in proportion and $t$ tests for continuous variables. + For the dock workers, due to variable working conditions, the samples may not be representative of average work exposure to grain dust.

\section{PREVALENCE OF CHRONIC RESPIRATORY SYMPTOMS}

The figure shows that there were no significant differences in the frequency of reported asthma. The prevalence of chronic cough and phlegm was five to seven times higher for both groups of workers exposed to grain than that of the civic workers. The prevalence of occasional wheeze and dyspnoea for the exposed workers was twice as great as those of the controls.

A multiple logistic regression analysis was applied in which adjustment was made for the influences of smoking and years of employment in the industry (which was substituted

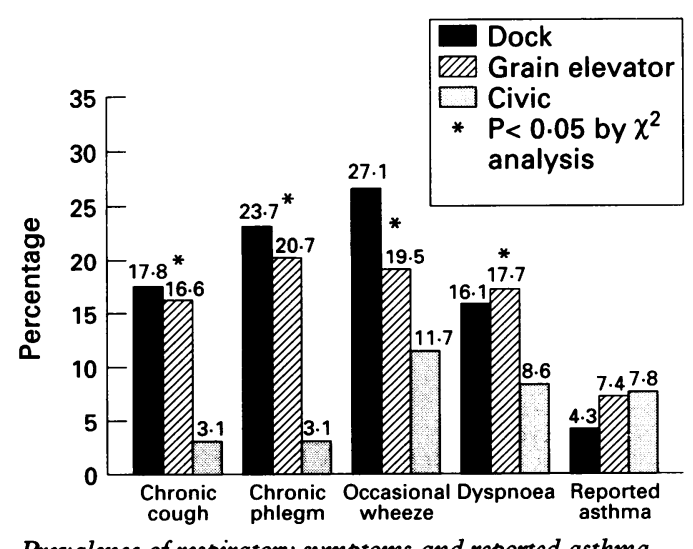

Prevalence of respiratory symptoms and reported asthma among dock, elevator, and civic workers. 
Table 3 Odds of developing respiratory symptoms: dock workers $v$ elevator and civic workers (with adjustments made for smoking and duration of employment)

\begin{tabular}{lll}
\hline Symptom & Comparison & OR $(95 \%$ CI*) \\
\hline Chronic cough & Dock $v$ civic & $5.33(1.69-16 \cdot 8)$ \\
& Dock $v$ elevator & $0.78(0.45-1 \cdot 36)$ \\
Chronic phlegm & Dock $v$ civic & $8 \cdot 18(2 \cdot 66-25 \cdot 2)$ \\
& Dock $v$ elevator & $0.83(0.50-1 \cdot 36)$ \\
Occasional wheeze & Dock $v$ civic & $2.77(1.33-5 \cdot 78)$ \\
& Dock $v$ elevator & $1.22(0.74-2 \cdot 00)$ \\
Shortness of breath & Dock $v$ civic & $1.53(0.65-3.62)$ \\
& Dock $v$ elevator & $0.55(0.31-0.99)$ \\
\hline
\end{tabular}

*The comparison is significant for a $95 \%$ CI that does not include 1 .

for age, with which it was highly correlated, $r=0.81$ ) in the comparisons of dock workers with either the elevator or civic workers. Table 3 gives adjusted odds ratios (ORs) and $95 \%$ confidence intervals ( $95 \%$ CIs). The likelihood of reporting either chronic cough, phlegm, or occasional wheeze was much greater for the dock workers than for the unexposed civic workers-for example, the risk of developing chronic phlegm was eightfold higher for the dock workers. Apart from the risk of developing dyspnoea, which was higher for the elevator workers, there were no distinct differences between the groups exposed to grain.

PREVALENCE OF RESPIRATORY SYMPTOMS AND GRAIN FEVER WHEN WORKING WITH GRAIN Table 4 compares the responses of dock workers in the 1991 study to questions on symptoms that occurred when working with grain, with those of elevator workers who

Table 4 Percentage of dock and elevator workers who had symptoms associated with exposure to grain dust

\begin{tabular}{|c|c|c|}
\hline & $\begin{array}{l}\text { Dock (\%) } \\
(n=115)\end{array}$ & $\begin{array}{l}\text { Elevator (\%) } \\
(1988 \text { study }) \\
(n=524)\end{array}$ \\
\hline \multicolumn{3}{|c|}{$\begin{array}{c}\text { Chest symptoms (cough, phlegm, wheeze, breathlessness that } \\
\text { occurred when working with grain) }\end{array}$} \\
\hline First began work ${ }^{\star}$ & $18 \cdot 8$ & $6 \cdot 1$ \\
\hline After a weekend & $4 \cdot 3$ & $4 \cdot 7$ \\
\hline After a long holiday & $10 \cdot 3$ & $11 \cdot 8$ \\
\hline \multicolumn{3}{|c|}{$\begin{array}{l}\text { Grain fever (fever and chills with either facial flushing, headache, } \\
\text { or muscle ache that occurred when working with grain) }\end{array}$} \\
\hline Working with certain grains* & $26 \cdot 3$ & $6 \cdot 7$ \\
\hline After a highly dusty exposure & $28 \cdot 0$ & $13 \cdot 5$ \\
\hline First began work $\star^{\star}$ & $11 \cdot 0$ & 4.5 \\
\hline After a long holiday & $6 \cdot 8$ & $5 \cdot 5$ \\
\hline
\end{tabular}

$\star \mathrm{P}<0.05 \chi^{2}$ test for differences in proportions.

Table 5 Prevalence of symptoms of general health experienced at least monthly at work

\begin{tabular}{|c|c|c|c|}
\hline Symptom & Dock & Elevator & Civic \\
\hline \multicolumn{4}{|l|}{ Irritation symptoms (\%): } \\
\hline Itching or burning eyes ${ }^{\star}$ & $62 \cdot 7$ & $32 \cdot 1$ & $14 \cdot 1$ \\
\hline Watery eyes ${ }^{\star}$ & $35 \cdot 6$ & $18 \cdot 6$ & $14 \cdot 1$ \\
\hline Burning nose or throat* & $16 \cdot 9$ & $8 \cdot 1$ & $2 \cdot 3$ \\
\hline Dry throat* & $27 \cdot 1$ & $20 \cdot 5$ & $13 \cdot 3$. \\
\hline Burning or itching skin ${ }^{\star}$ & $26 \cdot 3$ & $15 \cdot 9$ & $1 \cdot 6$ \\
\hline Skin rash ${ }^{\star} \ddagger$ & $27 \cdot 4$ & 25.9 & $3 \cdot 1$ \\
\hline \multicolumn{4}{|l|}{ General symptoms (\%) } \\
\hline Headache & $16 \cdot 9$ & $17 \cdot 8$ & $18 \cdot 8$ \\
\hline Blurred vision & 8.5 & $6 \cdot 5$ & $7 \cdot 0$ \\
\hline Ringing in ears & $9 \cdot 3$ & $9 \cdot 2$ & $5 \cdot 5$ \\
\hline Build up of saliva ${ }^{\star}$ & $12 \cdot 7$ & 7.9 & $2 \cdot 3$ \\
\hline Dizziness & $3 \cdot 4$ & $2 \cdot 9$ & $3 \cdot 1$ \\
\hline Chest pain & $6 \cdot 8$ & $5 \cdot 2$ & $4 \cdot 7$ \\
\hline Irregular heartbeat & $3 \cdot 4$ & $2 \cdot 3$ & 1.6 \\
\hline Nausea or vomiting ${ }^{\star}$ & 5.9 & $1 \cdot 4$ & 0.8 \\
\hline Abdominal cramps or pain $\dagger$ & $7 \cdot 6$ & $2 \cdot 2$ & $3 \cdot 7$ \\
\hline Numbness or tingling ${ }^{\star}$ & $11 \cdot 0$ & $4 \cdot 5$ & $1 \cdot 6$ \\
\hline Finger or hand tremors & $5 \cdot 1$ & $4 \cdot 5$ & $3 \cdot 1$ \\
\hline
\end{tabular}

$\star \mathrm{P}<0.05 \chi^{2}$ test and Mantel-Haenszel test for linearity; $+\mathrm{P}<0.05 ; \chi^{2}$ test only; Ғany occurrence of symptoms after employment in the industry. answered the same questions in a 1988 survey. A greater proportion of dock workers $(18.8 \% v 6 \cdot 1 \%)$ experienced at least one of the chest symptoms of cough, phlegm, wheeze, or shortness of breath when they first started working with grain. This difference was less pronounced among non-smokers and ex-smokers, and even more pronounced for smokers. Grain fever was consistently more common among the dock workers whether the exposure to grain dust occurred when first beginning their job or after a high dust exposure. Most of the dock workers who had experienced this flu like illness, attributed it to exposure to barley. The differences in the prevalence of grain fever were always significant for ex-smokers (data not shown).

\section{OTHER SYMPTOMS}

Workers from all three study groups were asked whether they had experienced several different symptoms that started while at work and occurred at least once a month. All symptoms of skin and mucous membrane irritation (table 5) showed a significant gradient, being highest among the dock workers and lowest for the civic workers. Eye irritation, described as itching burning eyes, was experienced by $63 \%$ of dock workers and was the most frequent complaint. The symptoms most commonly experienced by both groups of workers exposed to grain were all symptoms of mucous membrane irritation. The symptoms for the elevator workers were similar to those of the dock workers, but slightly less frequent. Symptoms such as headache, dizziness, and ringing in the ears were not significantly different among the groups.

\section{LUNG FUNCTION}

Table 6 shows the average percentage of predicted $\mathrm{FEV}_{1}, \mathrm{FVC}$, and $\mathrm{MMF}$, adjusted for differences in smoking between the three groups. The adjusted values of $\mathrm{FEV}_{1}$ and FVC for dock workers were intermediate between the lowest levels for the elevator workers and the highest levels for the civic workers. The differences in these lung function variables were significant between dock workers and elevator workers, but not between dock workers and civic workers. The dock workers had the highest MMFs, and no differences were found for the ratio of $\mathrm{FEV}_{1} / \mathrm{FVC}$.

To assess the effect of pattern of exposure of dock and elevator workers, regression analyses were done where $\mathrm{FEV}_{1}, \mathrm{FVC}$, and MMF were each analysed as the dependent variable. Variables found not to be significant

Table 6 Percentage of predicted lung function adjusted for smoking

\begin{tabular}{llcl}
\hline & $\begin{array}{l}\text { Dock } \\
(n=111)\end{array}$ & $\begin{array}{l}\text { Elevator } \\
(n=534)\end{array}$ & $\begin{array}{l}\text { Civic } \\
(n=122)\end{array}$ \\
\hline FEV $^{\star}$ & $100 \cdot 6$ & $96 \cdot 6 \dagger$ & $100 \cdot 9$ \\
FVC $^{\star}$ & $105 \cdot 3$ & $102 \cdot 3 \dagger$ & 107.7 \\
FMF $^{\star}$ & $90 \cdot 4$ & $83.3 \dagger$ & $81 \cdot 4 \ddagger$ \\
FEV $_{1} /$ FVC & 95.5 & $94 \cdot 1$ & 93.8 \\
\hline
\end{tabular}

$\star P<0.05$ one way analysis of covariance; $+P<0.05$; dock $v$ elevator workers; $\ddagger \mathrm{P}<0.05$ dock $v$ civic workers. 
Table 7 Predictors of lung function for the combined group of dock and elevator workers by multiple regression analysis*

\begin{tabular}{|c|c|c|c|}
\hline Lung function predictor & $\begin{array}{l}\text { Effect } \\
\text { (coefficient }\end{array}$ & $S E M$ & P value \\
\hline \multicolumn{4}{|l|}{ FEV $_{1}(\mathrm{ml})$ : } \\
\hline Exposure duration ( $\mathrm{h} /$ day) & $-20 \cdot 6$ & $9 \cdot 8$ & $<0.05$ \\
\hline Age $(y)$ & $-35 \cdot 5$ & $2 \cdot 1$ & $<0.001$ \\
\hline Current smoker & $-172 \cdot 5$ & $52 \cdot 4$ & $<0.001$ \\
\hline Dock ( $v$ elevator) & 155.9 & $55 \cdot 8$ & $<0.01$ \\
\hline Height $(\mathrm{cm})$ & $46 \cdot 1$ & $3 \cdot 0$ & $<0.001$ \\
\hline Race (not white) & $-154 \cdot 7$ & $78 \cdot 1$ & $<0.05$ \\
\hline \multicolumn{4}{|l|}{ FVC (ml): } \\
\hline Exposure duration (h/day) & $-9 \cdot 2$ & $11 \cdot 3$ & NS \\
\hline Age (y) & $-30 \cdot 0$ & $2 \cdot 4$ & $<0.001$ \\
\hline Current smoker & $-58 \cdot 0$ & $60 \cdot 7$ & NS \\
\hline Dock ( $v$ elevator) & $151 \cdot 9$ & $64 \cdot 7$ & $<0.05$ \\
\hline Height $(\mathrm{cm})$ & $67 \cdot 3$ & $3 \cdot 4$ & $<0.001$ \\
\hline Race (not white) & $-219 \cdot 6$ & $90 \cdot 5$ & $<0.05$ \\
\hline \multicolumn{4}{|l|}{$\mathrm{MMF}(\mathrm{ml} / \mathrm{s}):$} \\
\hline Exposure duration (h/day) & $-37 \cdot 0$ & $20 \cdot 8$ & $<0.09$ \\
\hline Age (y) & $-63 \cdot 6$ & 4.5 & $<0.001$ \\
\hline Current smoker & $-514 \cdot 5$ & $111 \cdot 2$ & $<0.001$ \\
\hline Dock ( $v$ elevator) & $-328 \cdot 8$ & $118 \cdot 6$ & $<0.01$ \\
\hline Height (cm) & $20 \cdot 6$ & $6 \cdot 3$ & $<0.005$ \\
\hline Race (not white) & $-178 \cdot 4$ & $165 \cdot 8$ & NS \\
\hline
\end{tabular}

*Variables found to be significant for at least one lung function are included; variables entered into the models, but found not to be significant were ex-smokers, atopy, use of mask, month employed in the industry or job, and exposure frequency.

for any of the lung function variables included ex-smokers, atopy, use of a mask, months employed in the job and industry, and frequency of exposure. Table 7 shows the regression coefficients derived for predictors that were found to be significant. Duration of exposure to grain dust (hours a day) was found to be significant in predicting $\mathrm{FEV}_{1}$ but not quite significant in predicting MMF. The average number of days worked was also considered by combining the two variables frequency and duration of exposure to create a variable of the average number of hours worked a month. The conclusions were the same as those found for duration of exposure only (data not shown).

\section{Discussion}

In comparison with civic workers who have had no exposure to grain dust, dock and elevator workers had a high prevalence of chronic respiratory symptoms. Yet lung function variables for dock workers were no different from the controls, and on average they had higher $\mathrm{FEV}_{1}$ and FVC values than those found for the grain elevator workers.

This paradox may be a result of differences in their work exposures to grain dust. Based upon the questionnaire and observed work practices, in contrast with grain elevator workers whose exposure to grain dust is continuous, although not constant while at work, dock workers are exposed to grain intermittently during the working day and work a variable number of days at loading grain cargoes. The exposure of dock workers to grain dust can at times be considerable, but the dock workers do have the opportunity to spend much of their time at resting stations inside the ships, away from the loading areas.

Short term exposures to grain dust have been shown to cause a reduction in lung function, as measured after only three weeks ${ }^{9}$ or after one year of employment. ${ }^{10}$ Broder and colleagues found that FVC, $\mathrm{FEV}_{1}$, and flow rates increased during the winter months in Thunder Bay, Ontario for those elevator workers laid off and for the others who worked under reduced elevator activity, because of freezing of the water transport corridors. ${ }^{11}$ After rehire and return to full activity, the lung function levels for these elevator workers were once again reduced. The effects of exposure to grain dust on long term changes in respiratory variables were suggested to be at least partially reversible.

Due to the intermittent exposures to grain dust, some recovery of the decline in lung function may have been possible for the dock workers. The inverse relation between estimates of daily exposure to grain dust and $\mathrm{FEV}_{1}$ supports this hypothesis, but cannot distinguish between intermittency or reduction in total duration of exposure as the mechanism to explain the higher average level of $\mathrm{FEV}_{1}$ found in dock workers. The individual dock worker's exposures to grain are too variable to allow for further modelling of exposure-response relations as published previously for elevator workers ${ }^{5}$ and animal feed workers. ${ }^{12}$

In contrast with the slowdown in activity occurring in Thunder Bay during the winter months, Vancouver grain elevators are operational at full activity all the year round due to a milder climate, and overtime work is common. By contrast with findings of no differences in long term decline in lung function between Thunder Bay elevator workers and controls $^{13}$ long term decreases in lung function of Vancouver elevator workers were found to be significantly greater than for the controls after three years of follow up, and for non-smokers only after six years. ${ }^{214}$ For the Thunder Bay grain elevator workers, interrupted exposure conditions may provide an opportunity for some reversibility in the decline of lung function, apart from considerations of differences in the composition of the grain dust.

A greater use of masks while at work among dock workers could have some bearing on the findings of their higher pulmonary function, although this was not found to be predictive of lung function. The question on use of masks was answered for current work practices only and may not represent past use.

As the analyses were based on cross sectional sampling, all three worker groups are more prone to the healthy worker effect than the general population. This is especially pertinent to the study of a survivor population of grain workers. ${ }^{15}$ Differential selection may explain many of the differences in respiratory health found among the three groups. Dock workers in particular have a choice of whether to work in this aspect of the industry, without jeopardising their employment. The comparatively low rates of atopy seen in the dock workers supports a hypothesis of selective exclusion of atopic subjects. ${ }^{16}$ It has been suggested that atopic subjects tend to experience more adverse respiratory symptoms, which may discourage them from remaining employed in the industry. ${ }^{9}$ 
The relatively normal lung function levels for dock workers, comparable with those for the unexposed controls, are consistent with a previous study on dock workers who handled grain. ${ }^{3}$ For the 80 dock workers studied in England, the average unadjusted values for $\mathrm{FEV}_{1}$ and FVC were $100 \cdot 7 \%$ and $109 \cdot 7 \%$ respectively. It was concluded that no abnormalities in lung function in the exposed population were detected; however, no comparison controls were available.

For all the symptoms of eye and skin irritation and for the many other symptoms that differed between the groups, dock workers consistently showed the highest prevalence. The finding that not all symptoms were uniformly increased for dock workers, such as headache or blurred vision, supports the validity of the findings of excessive irritation of the mucous membrane. Periods without exposure may enhance the worker's sensitivity to the irritant effects of grain dust, particularly where the brief exposures are intense. For instance, newly hired grain workers developed an excess of respiratory symptoms that decreased by the time they were laid off. ${ }^{3}$ Indirect evidence of high dust exposure was the relatively high proportion of dock workers who had a history of grain fever $(28 \%$ after high dust exposures). Such a prevalence of grain fever was comparable with that experienced by grain handlers, including longshoremen, reported in a 1980 Montreal study, ${ }^{4}$ and is reminiscent of the rates found for grain elevator workers examined 20-50 years ago when grain dust levels were generally poorly controlled. ${ }^{17-19}$

To assess the respiratory health of the dock workers relative to their exposure to grain dust may be complicated because of other dust exposures from the many different bulk cargoes that they have handled. The impact of many of these dusts on respiratory function may, however, be small. For instance, when the lung function of 38 longshoremen from the Port of Montreal who handled general cargoes (not grain) were compared with 103 grain handlers, including longshoremen who loaded grain, the flow volume characteristics and dynamic lung volumes were found to be higher for the port workers not exposed to grain, particularly among the non-smokers. ${ }^{4}$

In conclusion, the study of dock workers who load grain has showed distinct differences in their respiratory health compared with both unexposed controls and grain elevator workers. Although findings were consistent with other publications in showing a greater prevalence of respiratory symptoms in these workers exposed to grain than in controls, unlike the elevator workers the average lung function of the dock workers was not lower than the controls. The dock workers were exposed on a much more intermittent basis over the working day and working week. It was hypothesised that the more intermittent exposure to grain dust may have allowed for some recovery of lung function, but chronic respiratory symptoms were less labile.

We acknowledge Roxanne Rousseau for conducting interviews and the helpful organisational efforts of Eric Skowronek of British Columbia Maritime Employers Association and Tom Dufresne of local 500, International Longshoremen's and Warehousemen's Union. The Labour Canada staff, particularly Jill Walker and Lynn Peters, were most supportive. This larly Jill Walker and Lynn Peters, were most supportive. This work was supported by grants from the British Columbia Lung
Association, Labour Canada, and the British Columbia Association, Labour Canada,
Terminal Operators' Association.

1 Chan-Yeung M, Dimich-Ward H, Enarson DA, Kennedy SM. Five cross-sectional studies of grain elevator workers. Am ₹ Epidemiol 1992;136:1269-79.

2 Chan-Yeung M, Enarson DA, Kennedy SM. The impact of grain dust on respiratory health. Am Rev Respir Dis 1992;145:476-87.

3 Cockcroft AE, McDermott M, Edwards JH, McCarthy P. Grain exposure-symptoms and lung function. Eur $\mathcal{f}$ Grain exposure-symptom

4 Becklake MR, Jodoin G, Lefort L, Rose B, Mandl M, Fraser RG. In: Dosman JA, Cotton DJ, eds Occupational pulmonary disease focus on grain dust and health. New York: Academic Press, 1980:239-55.

5 Huy T, Schipper KD, Chan-Yeung M, Kennedy SM Grain dust and lung function. Dose-response relationships. Am Rev Respir Dis 1991;144:1314-21.

6 American Lung Association. Recommended respiratory disease questionnaire for use with adults and children in respiratory research Am Rev Respir Dis 1978:118:7-53.

7 respiratory reseach $A m$ use American Thoracic Society. Standardization of spirometry-1987 update. Am Rev Respir Dis 1987;136:1285-98.
Crapo RO, Morris AH, Gardner RM. Reference spirometCrapo RO, Morris AH, Gardner RM. Reference spiromet-
ric values using techniques and equipment that meet ATS recommendations. Am Rev Respir Dis 1981; 123:659-64.

9 James AI, Cookson WOCM, Buters G, Lewis S, Ryan G Hockey R, Musk AW. Symptoms and longitudina changes in lung function in young seasonal grain handlers. Br F Ind Med 1986;43:587-91.

10 Zejda JE, Pahwa P, Dosman JA. Decline in spirometric variables in grain workers from start of employment: differential effect of duration of follow-up. $\mathrm{Br} \mathcal{F}$ Ind $\mathrm{Med}$ 1992;49:576-80.

11 Broder I, Mintz S, Hutcheon MA, Corey PN, Kuzyk J. Effect of layoff and rehire on respiratory variables of Erfect of layoff and rehire on respiratory variables of grain $601-8$.

12 Smid T, Heederik D, Houba R, Quanjer PH. Dust- and endotoxin-related respiratory effects in the animal feed industry. Am Rev Respir Dis 1992;146:1474-9.

13 Broder I, Corey P, Davies G, Hutcheon M, Mintz S, Inouye $\mathrm{T}$, et al. Longitudinal study of grain elevator and control workers with demonstration of healthy worke effect. $\mathcal{F}$ Occup Med 1985;27:873-80.

14 Chan-Yeung M, Schulzer M, MacLean L, Dorken E, Tan F, Lam S, et al. A follow-up study of the grain elevator workers in the Port of Vancouver. Arch Environ Health workers in the Por

15 Bachmann M, Myers JE. Grain dust and respiratory health in South African milling workers. Br f Ind Med 1991; in South $A$

16 Gerrard JW, Mink J, Sze-Schuen CC, Cheung C, Tan LK-T, Dosman JA. Nonsmoking grain handlers in Saskatchewan: airways reactivity and allergic status. f Occup Med 1979;21:342-6.

17 Smith AR, Greenburg L, Siegel W. Respiratory disease among grain handlers. Industrial Bulletin 1941;20:1.

18 Kleinfeld M, Messite J, Swencicki RE, Shapiro J. A clinical and physiological study of grain handlers. Arch Environ Health 1968;16:380-4.

19 Tse KS, Warren P, Janusz M, McCarthy DS, Cherniack RM. Respiratory abnormalities in workers exposed to grain dust. Arch Environ Health 1973;27:74-7. 